\title{
THE IMPACT OF CLIENT IMPORTANCE ON EARNINGS MANAGEMENT AND GOING-CONCERN OPINION: EMPIRICAL EVIDENCE FROM INDONESIA
}

\author{
Amelia Susanto \\ Universitas Pelita Harapan \\ e-mail: ameliasusanto25@gmail.com \\ Antonius Herusetya \\ Universitas Pelita Harapan \\ e-mal : antonius.herusetya@uph.edu.
}

\begin{abstract}
This study investigates the impact of client importance on auditor independence measured by accrual earnings management and going-concern opinion. Our research sample consists of 1,080 firm-years of observation from listed companies in the Indonesia Stock Exchange (IDX) with eight years of observation (2004-2011). With pooled OLS we found that client importance has a negative impact on accrual earnings management. We also found evidence that client importance has a positive impact on going-concern opinion. Collectively, our evidence suggests that although audit firms have economic dependence toward their clients, those audit firms can maintain their audit quality by keeping their independency toward their clients, reflected by the lower accrual earnings management and higher tendency of issuing going-concern opinion. Our results are robust by considering the results of our sensitivity tests that support the main results.
\end{abstract}

Keywords: audit quality, auditor independence, client importance, earnings management, going-concern opinion

\begin{abstract}
Abstrak
Penelitian ini menguji pengaruh kepentingan klien terhadap independensi auditor yang diukur dengan manajemen laba berbasis akrual dan opini going-concern. Sampel penelitian terdiri dari 1.080 observasi dalam tahun-perusahaan dari perusahaan terdaftar di Bursa Efek Indonesia (BEI) dengan delapan tahun pengamatan (2004-2011). Dengan menggunakan pooled OLS, kami menemukan bahwa kepentingan terhadap klien (client importance) berpengaruh negatif terhadap manajemen laba akrual. Kami juga menemukan bukti bahwa kepentingan terhadap klien berpengaruh positif terhadap opini going-concern. Secara keseluruhan, temuan-temuan kami menyimpulkan bahwa walaupun Kantor Akuntan Publik memiliki kepentingan ekonomi terhadap klien, namun Kantor Akuntan Publik memelihara kualitas audit dengan menjaga tingkat independensi terhadap klien mereka, tercermin dari manajemen laba akrual yang lebih rendah, dan terdapat kecenderungan yang lebih tinggi dalam memberikan opini going-concern. Hasil studi ini robust setelah mempertimbangkan hasil dari pengujian sensitivitas yang mendukung pengujian utamanya.
\end{abstract}

Kata kunci: kualitas audit, independensi auditor, kepentingan terhadap klien, manajemen laba, opini going-concern

\section{INTRODUCTION}

The audit quality of public accounting firms has been criticized in the last decade, since they could not protect the interests of investors (Coffee 2002; 2003; Levitt 1998). This audit quality has been defined by various definitions. DeAngelo (1981), for example, defines audit quality as the joint probability that the auditor will find a breach in the client's accounting system, and report that violation. In this definition, audit 
quality covers the dimensions of competence and independence. Fitriany (2011) suggests that a higher degree of compentence from auditors is not always be accompanied by a higher degree of independence. In terms of independence, audit quality can be measured from different aspects, i.e., economic dependence toward clients, the influence of client practices toward the propensity to meet earnings targets, corporate governance practices, the propensity to issue going-concern opinions, the conducted peer review, or other measure of independence (Bamber and Bamber 2009).

Due to the auditor-client relationship, auditors may have incentives to compromise with their clients depending on the auditors' economic interests on their clients (DeAngelo 1981; Reynolds and Francis 2001). The proposition that the auditors will report favorably to retain important clients is known as the economic bonding (DeAngelo 1981). The independence of auditors can be reflected in the extent to which auditors will toleate opport unistic earnings management, and how likely the auditors will issue going-concern opinion (Herusetya 2012; Francis and Yu, 2009).

Most of prior studies found that economic dependence does not encourage larger clients to perform greater discretions in accrual-based earnings management (e.g., Reynold and Francis 2001; Francis and Yu 2009; Herusetya 2012). Some previous studies found evidence that auditor independence impaired when clients pay for non-audit services is relatively higher compared to the total fee (Frankel, Johnson and Nelson 2002). They found evidence of a positive association between client importance (i.e., the ratio of non-audit services to total fee) and the amount of discretionary accruals. While Chung and Kallapur (2003) found no evidence on the association between client importance and abnormal accruals.

Past research also found the association between client importance and audit opinion issued by public accounting firms (e.g., Reynolds and Francis 2001; Craswell, Stokes and Laughton 2002; Chen, Sun and Wu 2010). Reynolds and Francis (2001) found that Big 5 did not treat larger clients with more compro- mise than smaller clients based on the size of individual practice offices, i.e., by not reducing the propensity to issue going-concern opinions. Existing financial incentives were considered enough to motivate the auditors to be independent, despite the fact that the presence of economic dependence relationships was inherently in the auditor-client contract. Similarly, Craswell et al. (2002) found that fee dependence as a threat to auditor independence does not affect the likelihood of auditors to issue qualified audit opinions, both at national and local market levels.

The lack of evidence on the previous studies, which examined the associations between client importance, earnings management, and going-concern opinion are the main reasons of our study. The lack of past research on auditor independence in Indonesia, as measured by the economic dependence of auditors toward their clients will make some contributions to this study. First, Marchesi (2000) for example, found that audit quality in ASEAN countries was so compromise. But as the climate of audit environment in the United States has started to change since the corporate failure in 2001, which also gave impact to the legal and audit environment around the world including Indonesid (Fargler and Jiang 2008; Chen et al. 2010), we expect to provide evidence on these associations. Secondly, past researches on audit quality were more dominated by the measurement of the competence dimension, for example, using the size of accounting firms (Big 4, etc) (Fitriany 2011; Siregar 2006; Francis 2004). Audit quality of the Big 4 firms in Indonesia may differ from the Big 4 firms in the United States who are under the Sarbanes Oxley Acts (Gordon et al. 2013). Our study contributes to the measurement of independence of the audit firms in Indonesia using a proxy of client importance which includes a sample of the Big 4 firms.

\section{LITERATURE REVIEW AND HYPO- THESIS DEVELOPMENT}

Client Importance as a Measure of Auditor Independence 
It was long been a suspicion that the auditors' financial interest toward their clients can greatly affect the auditor independence (Mautz and Sharaf 1961 in Chen et al. 2010). DeAngelo (1981) suggests that auditors' incentives to compromise their independence toward their client depends on the importance of a client to the auditor (client importance), i.e. the ratio of quasi rents specific to the client divided by the total number of quasi rents received by the auditor.

DeAngelo (1981) observed that if the percentage of the entire fee depends on one client used as a measure of audit quality (i.e., perceived independence with respect to that client) then the audit quality will decrease. The proposition that auditors will report favorably to retain important clients is known as economic bonding (DeAngelo 1981; Francis and Yu 2009), fee dependence, or economic dependence (Reynolds and Francis, 2001; Chen et al. 2010). It is probable that the greater the size of the clients in auditor's portfolio, the greater the incentive for the auditor to retain his clients, in which audit quality is likely to be compromised (Chen et al.2010).

\section{Client Importance and Earnings Management}

Since the corporate scandals involving auditors in the United States by the end of 2001 that gave birth to the Sarbanes-Oxley Act (SOX) of 2002, the change of audit environment is also felt through over the world, including Indonesia. The Indonesian Government issued various regulations concerning the audit services provided by audit firms. These regulations were expected to increase the competence and the independence of the auditors (Herusetya 2012).

Auditor independence can be reflected in the extent to which the auditor became more tolerant to the earnings management done by the clients. The higher the quality of the independence of the auditors, the lower the earnings management behavior was reflected. Previous research has examined the association between client importance and earnings management (e.g., Herusetya 2012; Reynolds and Francis 2001; Frankel et al. 2002; Chung and Kallapur 2003; Francis and Yu 2009).

Reynolds and Francis (2001) examined the association between client importance and audit outcome, i.e. total accruals and total discretionary accruals as measures of earnings quality. They suspect that the client importance (INFLUENCE variable) at the level of individual practice office can reduce auditor independence, but they found that Big 5 auditors did not treat larger clients more compromisingly compared to smaller clients.

With a sample of 6,568 U.S. firmsyears observations for the period 2003 to 2005, Francis and $\mathrm{Yu}$ (2009) examined whether the larger offices of Big 4 auditors have higher audit quality. Using an INFLUENCE variable as a measure of the auditor's incentives with respect to a fee-dependence and used as a control variable, they found that larger Big 4 practice offices have a negative association with absolute abnormal accruals. Herusetya (2012) in his study used a composite measure of audit quality that covered the dimension of competence and independence, and client importance (CI) was one of the proxies used in the dimension of independence. By using a single proxy of CI, he found that $\mathrm{CI}$ has a negative association with the absolute discretionary accruals.

In summary these findings conclude that even though the auditors have economic dependence on their clients, but the auditors do not encourage greater discretion in accrualbased earnings managemen $\mathbf{H}$. In other words, the auditors do not provide greater tolerance to earnings management behavior for their important clients Based on the arguments given above, the hypothesis to be tested is:

$\mathrm{H}_{1}$ : Client importance is negatively associated with earnings management.

\section{Client Importance and Going-Concern Opinion}

Auditor's independence can be reflected in the propensity to issue going-concern opinion. Auditor independence will decline if the auditor compromise not to report the financial condition of the clients related to going- 
concern problems, because the auditor has economic dependence to the client (DeAngelo 1981; Reynold and Francis 2001).

Previous research found evidence on the association of client importance and audit opinion issued by public accounting firms (Reynolds and Francis 2001; Craswell et al. 2002; Chen et al. 2010) Reynolds and Francis (2001) found that Big 5 did not treat large clients with more compromise than the smaller clients. Reynolds and Francis (2001) found the size of individual practice offices of the Big 5 did not reduce the propensity to issue goingconcern opinion. Existing financial incentives were considered enough to motivate the auditor to be independent, despite the fact that the presence of economic dependence relationships was inherently in the auditor and client contract. Similarly, Craswell et al. (2002) found that the fee dependence as a threat to auditor independence does not affect the likelihood of auditors to issue a qualified audit opinion, both at the national and local market levels.

Chen et al.(2010) conducted a study in China, and found that the level of auditor independence increase in line with the improvement of legal and regulatory environment. Chen et al. (2010) found that after 2001, when the legal and regulatory environment began to grow well in China, the tendency for clients to receive modified audit opinion (MAO) is higher compared to the period before 2001 (i.e., 1995-2000) for client importance measured by individual auditors. Similarly, Li (2009) found that after the period of SOX in the United States, higher audit fees and total audit fee ratio have a positive associ- ation with the auditor's propensity to issue going-concern opinion. The findings of $\mathrm{Li}$ (2009) and Chen et al. (2010) provide additional evidence that in line with the improvement of the institutional and regulatory climate, the tendency of auditors to compromise in audit quality seems to decrease, given the risks of litigations and penalties for auditors are higher than the economic incentives they earned. Based on the above arguments, the hypothesis will be tested is:

$\mathrm{H}_{2}$ : Client importance is positively associated with the propensity to issue going-concern Opinion

\section{RESEARCH METHODOLOGY}

\section{Population and Sample}

Population of this research is all listed companies in IDX along the year 2004-2011. Sample selection is performed with the criteria as follows: a) Companies issued annual report each year, with the fiscal year ended at December 31, starting from year 2004 to 2011. b) Companies are fully operated from 2004 to 2011 and not included new listing (IPO) companies from 2004 to 2011. c) Companies are never delisted from IDX, discontinued its activities as well as merger. d) The sample does not include financial industries due to the classification of regulated industries (Balsam, Krishnan \&Yang, 2003; Francis \& Yu, 2009; Hermawan, 2009; Herusetya, 2012).

Based on the sample criteria, we obtained 135 final samples of company per year for 8 year-period (2004-2011), or 1,080 firmyears of observation of pooled OLS data.

Table 1: Sample Description

\begin{tabular}{lc}
\hline \multicolumn{1}{c}{ Description } & Total \\
\hline Number of firm-years observation from listed companies at IDX for the year 2004-2011 & 4,560 \\
Number of firm-years observation from financial industries & $(1,144)$ \\
Total preliminary sample & 3,416 \\
Number of firm-years observation from new listing and delisted companies in 2004-2011 & $(1,440)$ \\
Number of firm-years observation with incomplete data in 2004-2011 & $(696)$ \\
Number of firm-years observation that does not meet the minimal observations in each & $(200)$ \\
industry per year & 1,080 \\
Total final sample (firm-years) & 135 \\
Total final sample (company) & \\
\hline
\end{tabular}




\section{Empirical Model}

\section{Client Importance and Earnings Management}

Prior research used discretionary models to identify earnings management (Francis and Yu 2009; Reynolds and Francis 2001; Balsam et al. 2003). To test the association between client importance and accrual earnings management we use pooled-OLS of Model 1 as follows:

$$
\begin{aligned}
\text { ABSDAC }_{\mathrm{it}}= & \alpha_{0}+\alpha_{1} \mathrm{CI}_{\mathrm{it}}+\alpha_{2} \mathrm{SIZE}_{\mathrm{it}}+\alpha_{3} \\
& \mathrm{CFO}_{\mathrm{it}}+\alpha_{4} \mathrm{LEV}_{\mathrm{it}}+\alpha_{5} \mathrm{LOSS}_{\mathrm{it}}+ \\
& \alpha_{6} \mathrm{ABSTACC}_{\mathrm{it}}+\alpha_{7} \mathrm{SGRW}_{\mathrm{it}}+ \\
& \varepsilon_{\mathrm{it}} \ldots \ldots \ldots \ldots \ldots \ldots \ldots \ldots \ldots \ldots \text { Model } 1
\end{aligned}
$$

Hypothesis $\mathrm{H}_{1}$ of this research can be formulated in statistical form as follows:

$\mathrm{H}_{1}: \alpha_{1}<0$; the expectation for each variable control is: $\alpha_{2} \neq 0, \alpha_{3}<0, \alpha_{4}>0, \alpha_{5}<0, \alpha_{6}>0$, $\alpha_{7}>0$. All variables are defined as in Table 2 .

The main variable in Model 1 is CI, and the coefficient $\alpha_{1}$ is predicted negative and significant toward the absolute discretionary accruals (ABSDAC), which indicates that client importance has a negative association with accrual earnings management.

\section{Table 2: Variable Descriptions}

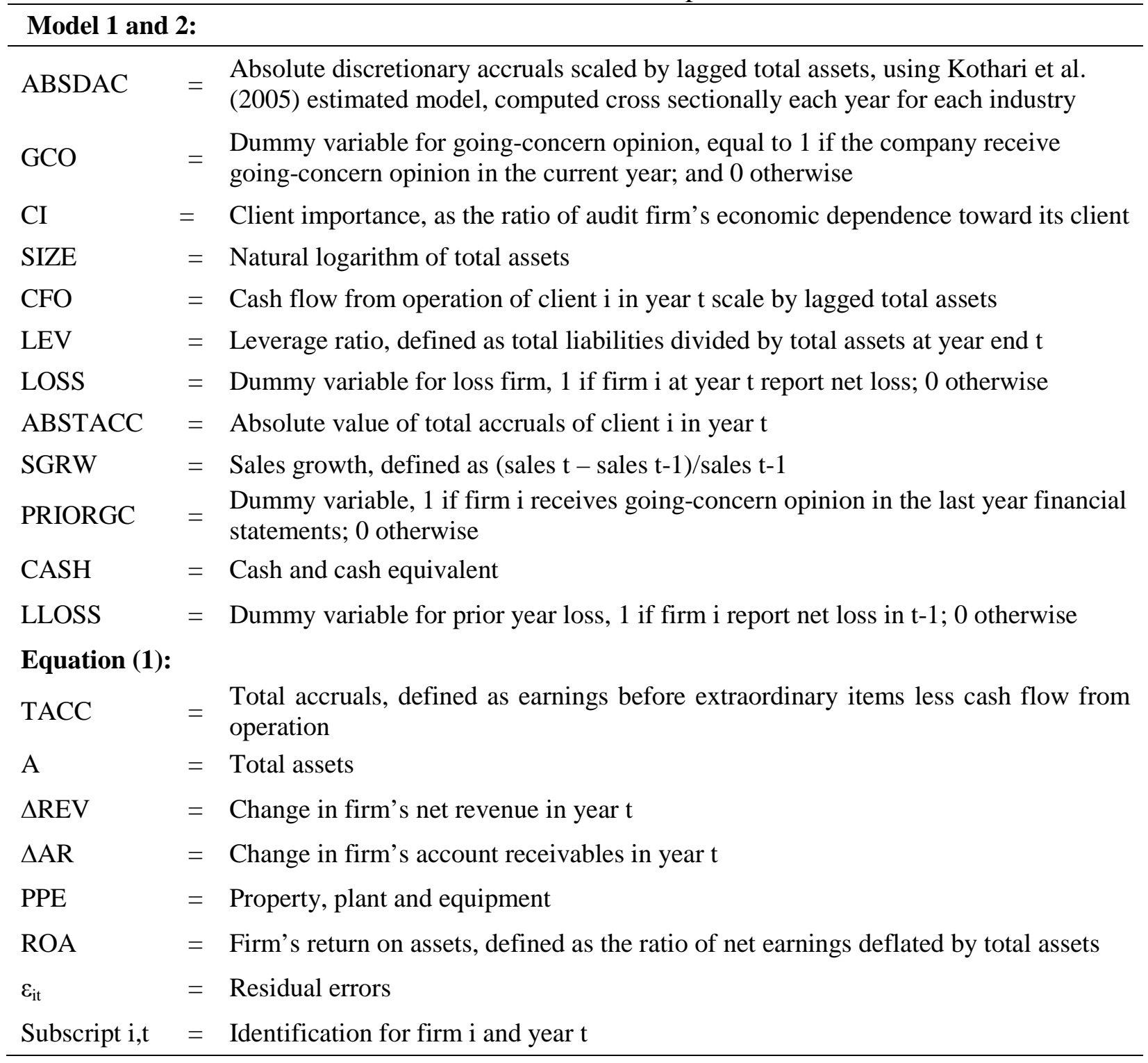


To control other factors that affect absolute discretionary accruals, we include several variables in Model 1. Clients with larger size (SIZE) has less discretionary accruals, due to larger clients have more resources to maintain the sustainability of the entity (Becker, Defond, Jiambalvo and Subramanyam, 1998; Reynolds and Francis, 2001; Balsam et al. 2003). However, large companies have also higher market pressure to meet analysts' expectations (Barton and Simko 2002), thus having greater opportunities to perform earnings management (Tresnaningsih 2008). Therefore we do not predict the sign of SIZE coefficient. Higher level of sales would increase accruals but will reduce operating cash flows (Dechow, Sloan and Sweeney 1995), thus we expect a negative sign for CFO coefficient. Companies with the higher level of liabilities (LEV) have more incentives to deal with earnings management compared to the lower level of liabilities (Reynolds and Francis 2001; Balsam et al. 2003), therefore leverage (LEV) is predicted to be positively related to ABSDAC. Dechow and Schrand (2004), and Francis and $\mathrm{Yu}$ (2009) found a negative association of the company with net loss toward its accruals quality, therefore LOSS coefficient is predicted negative. ABSTACC, the absolute value of total accruals scaled by total asets $t-1$ is used to control the propensity to generate accruals, and is predicted to have positive relationship with ABSDAC (Balsam et al. 2003; Francis and $\mathrm{Yu}$ 2009). McNichols (2000), and Menon and William (2004) found evidence that sales growth has a positive association with abnormal accruals, due to high growth companies have higher discretionary accruals adjustment. We predict SGRW has a positive association with ABSDAC.

\section{Client Importance and Going-Concern Opinion} Most prior research examined the propensity to issue going-concern opinion (e.g., Geiger, Raghunandan and Rama 2005; Reynolds and Francis 2001; Craswell et al. 2002; Francis and Yu 2009; Geiger and Rama 2006; Francis 2004). To test hypothesis $\mathrm{H}_{2}$, we use logistic regression of Model 2 to identify the effect of client importance toward going-concern opinion:

$$
\begin{array}{r}
\mathrm{GCO}_{\mathrm{it}}=\beta_{0}+\beta_{1} \mathrm{CI}_{\mathrm{it}}+\beta_{2} \mathrm{SIZE}_{\mathrm{it}}+\beta_{3} \mathrm{PRIORG} \\
\mathrm{C}_{\mathrm{it}-1}+\beta_{4} \mathrm{CASH}_{\mathrm{it}}+\beta_{5} \mathrm{LEV}_{\mathrm{it}}+\beta_{6} \\
\mathrm{LOSS}_{\mathrm{it}}+\beta_{7} \mathrm{LLOSS}_{\mathrm{it}}+\in \ldots . \text { Model } 2
\end{array}
$$

The statistical form of the hypothesis $\mathrm{H}_{2}$ of this research is as follows:

$\mathrm{H}_{2}: \beta_{1}>0$; the expectation for each control variable is: $\beta_{2}>0, \beta_{3}>0, \beta_{4}<0, \beta_{5}>0, \beta_{6}>0$, $\beta_{7}>0$. All variables are defined as in Table 2 .

The main variable in Model 2 is CI, and we estimate the coefficient $\beta_{1}$ is positive and significant toward going-concern opinion (GCO), which indicates that client importance has a positive association with the propensity to issue going-concern opinion. Several control variables included in the Model 2 to control other factors that may affect audit firms to issue going-concern reports. Companies with larger size (SIZE) have greater resources and are more likely to survive compared to smaller companies (Francis and $\mathrm{Yu}$ 2009), therefore we predict variable SIZE has a negative association with GCO. Companies that received going-concern opinion on the previous year (PRIORGC) are more likely to receive goingconcern opinion in the current year (Reynolds and Francis, 2001). CASH is a liquidity measure that is the sum of cash and cash equivalent, scaled by total assets. Companies with more liquid assets have more resources to deal with financial difficulties, therefore we expect CASH coefficient is negative. Companies with high debt levels (LEV) and experience net loss in the current year (LOSS) are more likely to fail and more likely to receive going-concern reports, therefore, we predict LEV and LOSS coefficients have positive associations with GCO (Francis and Yu 2009).

\section{Operational Variables Absolute Discretio- nary Accruals (ABSDAC)}

We use accrual model from Kothari, Leone and Wasley (2005) to measure the discretionary accrual which is as follows: 
$\mathrm{TACC}_{\mathrm{it}} / \mathrm{A}_{\mathrm{it}-1}=\alpha_{0}+\alpha_{1}\left(1 / \mathrm{A}_{\mathrm{it}-1}\right)+\beta_{1 \mathrm{i}}\left(\Delta \mathrm{REV}_{\mathrm{it}}{ }^{-}\right.$

$$
\begin{aligned}
& \left.\Delta \mathrm{AR}_{\mathrm{it}} / \mathrm{A}_{\mathrm{it}-1}\right)+\beta_{2 \mathrm{i}}\left(\mathrm{PP} \& \mathrm{E}_{\mathrm{it}} / \mathrm{A}_{\mathrm{it}-1}\right) \\
& +\gamma_{1} \mathrm{ROA}_{\mathrm{it}-1}+\epsilon_{1} \ldots \ldots \ldots \ldots \ldots \ldots \ldots \ldots . . .
\end{aligned}
$$

Discretionary accruals equal the value of residual errors $(\varepsilon)$ or the difference between total accruals and the fitted value of normal accruals, defined as $\mathrm{DA}_{\mathrm{it}}=\left(\mathrm{TACC}_{\mathrm{it}}\right)-\mathrm{NDA}_{\mathrm{it}}$ (Cohen, Dey and Lys 2008) The absolute value of discretionary accrual (ABSDAC) is used as a proxy of accrual earnings management by considering the possibility of positive and negative accrual earnings management (Myers, Myers and Omer 2003; Barton and Simko 2002; Cohen et al. 2008). All variables are defined as in Table 2.

\section{Going-Concern Opinion (GCO)}

GCO is a dummy variable $(1 ; 0)$, equal to 1 if the auditor assumes that the company cannot survive within 12 months after the balance sheet date, and receive going-concern opinion; and 0 if otherwise (Geiger et al.2005).

\section{Client Importance $(\mathrm{CI})$}

Client importance (CI) examines the tendency of auditors having economic dependence that may reduce the auditor independence (e.g., Frankel et al. 2002; Craswell et al. 2002; Chung and Kallapur 2003; Chen et al. 2010). Following Chen et al. (2010), we use natural logarithm of total client assets as a proxy of economic dependence with the following measurements:

$$
\mathrm{CI}_{\mathrm{it}}=\mathrm{SIZE}_{\mathrm{jt}} /\left[\sum_{i=1}^{n} \mathrm{SIZE}_{\mathrm{it}}\right] \ldots \ldots \ldots \ldots \ldots \ldots \ldots \ldots . .2
$$

Where:

$\mathrm{CI}_{\mathrm{it}}=$ client importance, as a measure of audit firm's economic dependence toward the client. SIZE $_{\text {it }}=$ natural logarithm of client's assets.

$\sum_{i=1}^{n} \mathrm{SIZE}_{\mathrm{it}}=$ the sum of total assets (in natural logaritm) from $n$ clients of certain audit firm.

\section{Control Variables}

We use control variables which have been used in the prior research as follows: company size (SIZE), cash flow from operation (CFO), leverage (LEV), net loss (LOSS), absolute value of total accruals (ABSTACC), prior year going-concern opinion (PRIORGC), cash and cash equivalents (CASH), sales growth (SGRW), prior year loss (LLOSS). See Table 2 for variable definitions.

\section{RESULTS AND DISCUSSION}

\section{Descriptive Statistics and Correlations}

The descriptive statistic of all operational variables can be seen on Table 3》The mean of ABSDAC in Table 3, Panel A is 0.110 or $11.0 \%$ of the total assets, indicating the magnitude of accrual earnings management. The mean of GCO (Panel B) is 0.230 indicating that the average firm-years observation to receive going-concern opinion is $23.0 \%$. The mean of CI is 0.239 , indicating that the average proportion of audit firms' revenue per client is $23.9 \%$. In Table 4 , CI variable has a positive correlation with $\mathrm{CGO}$ at a significance level of 0.01 , consistent with our prediction.

Table 3: Descriptive Statistics for Regression Variables

Panel A: Model 1

\begin{tabular}{lcccccc} 
& $\mathbf{N}$ & Minimum & Maximum & Mean & Std Deviation & Skewness \\
\hline ABSDAC & 1,080 & 0.000 & 2.319 & 0.110 & 0.168 & 5.843 \\
CI & 1,080 & 0.018 & 1.000 & 0.239 & 0.309 & 1.746 \\
SIZE & 1,080 & 6.339 & 18.849 & 13.574 & 1.687 & 0.129 \\
CFO & 1,080 & -1.617 & 1.082 & 0.067 & 0.148 & -1.639 \\
LEV & 1,080 & 0.000 & 5.025 & 0.543 & 0.512 & 3.736 \\
LOSS & 1,080 & 0.000 & 1.000 & 0.170 & 0.377 & 1.747 \\
ABSTACC & 1,080 & 0.000 & 2.465 & 0.101 & 0.154 & 6.047 \\
SGRW & 1,080 & -2.418 & 453.055 & 0.582 & 13.79 & 32.819 \\
\hline
\end{tabular}


Thelmpact of Client Importance ... (Amelia Susanto \& Antonius Herusetya)

Table 3

\begin{tabular}{lcccccc}
\hline \multicolumn{2}{l}{ Panel B: Model 2 } & & & & & \\
& $\mathbf{N}$ & Minimum & Maximum & Mean & Std Deviation & Skewness \\
\hline GCO & 1,053 & 0.000 & 1.000 & 0.230 & 0.424 & 1.255 \\
CI & 1,053 & 0.018 & 1.000 & 0.238 & 0.308 & 1.753 \\
SIZE & 1,053 & 6.339 & 18.849 & 13.590 & 1.689 & 0.122 \\
PRIORGC & 1,053 & 0.000 & 1.000 & 0.320 & 0.468 & 0.759 \\
CASH & 1,053 & 0.000 & 0.931 & 0.100 & 0.112 & 2.216 \\
LEV & 1,053 & 0.000 & 5.025 & 0.532 & 0.499 & 3.905 \\
LOSS & 1,053 & 0.000 & 1.000 & 0.170 & 0.372 & 1.805 \\
LLOSS & 1,053 & 0.000 & 1.000 & 0.190 & 0.394 & 1.568 \\
\hline
\end{tabular}

All variables are defined as in Table 2 .

Table 4: Pearson Correlations among Variables

Panel A: Model $1(n=1,080)$

\begin{tabular}{|c|c|c|c|c|c|c|c|c|}
\hline & ABSDAC & CI & SIZE & CFO & LEV & LOSS & ABSTACC & SGRW \\
\hline ABSDAC & 1.000 & & & & & & & \\
\hline CI & 0.039 & 1.000 & & & & & & \\
\hline SIZE & $-0.128^{* * *}$ & $-0.333^{* * *}$ & 1.000 & & & & & \\
\hline CFO & $-0.134 * * *$ & $-0.124 * * *$ & $0.159 * * *$ & 1.000 & & & & \\
\hline LEV & $0.247 * * *$ & $0.134 * * *$ & $-0.197 * * *$ & $-0.184 * * *$ & 1.000 & & & \\
\hline LOSS & $0.143 * * *$ & $0.123 * * *$ & $-0.209 * * *$ & $-0.191 * * *$ & $0.259 * * *$ & 1.000 & & \\
\hline ABSTACC & $0.914 * * *$ & $0.040^{*}$ & $-0.096 * * *$ & 0.002 & $0.253 * * *$ & $0.183^{* * *}$ & 1.000 & \\
\hline SGRW & 0.014 & -0.002 & -0.022 & $0.051^{* *}$ & -0.034 & -0.017 & 0.033 & 1.000 \\
\hline \multicolumn{9}{|c|}{ Panel B: Model $2(n=1,053)$} \\
\hline & GCO & CI & SIZE & PRIORGC & CASH & LEV & LOSS & LLOSS \\
\hline GCO & 1.000 & & & & & & & \\
\hline CI & $0.154 * * *$ & 1.000 & & & & & & \\
\hline SIZE & $-0.165^{* * *}$ & $-0.341 * * *$ & 1.000 & & & & & \\
\hline PRIORGC & $0.797 * * *$ & $0.130 * * *$ & $-0.161 * * *$ & 1.000 & & & & \\
\hline CASH & $-0.119 * * *$ & $-0.143 * * *$ & -0.004 & $-0.112 * * *$ & 1.000 & & & \\
\hline LEV & $0.309 * * *$ & $0.139 * * *$ & $-0.200 * * *$ & $0.226 * * *$ & $-0.146^{* * *}$ & 1.000 & & \\
\hline LOSS & $0.393 * * *$ & $0.135 * * *$ & $-0.196 * * *$ & $0.349 * * *$ & $-0.172 * * *$ & $0.258 * * *$ & 1.000 & \\
\hline LLOSS & $0.413 * * *$ & $0.150 * * *$ & $-0.231 * * *$ & $0.360 * * *$ & $-0.147 * * *$ & $0.216^{* * *}$ & $0.543 * * *$ & 1.000 \\
\hline
\end{tabular}

***, **, * significant at $0.01,0.05$, and 0.10 respectively. All variables are defined as in Table 2 .

\section{Test of Hypothesis $1\left(\mathrm{H}_{1}\right)$}

Hypothesis $\mathrm{H}_{1}$ predicts a negative association between client importance (CI) and accrualbased earnings management (ABSDAC). Empirical result of Model 1 in Table 5 has adjusted R-square of $85.68 \%$ with F-stat 923.766 (prob $<0.01)^{\beta}$ The coefficient of CI $\left(\alpha_{1}\right)$ is 0.011 (t-stat $=-1.303)$, negative but not significant at 0.10 with two-tailed test. However, the coefficient of $\mathrm{CI}$ is negative and significant at 0.10 with one-tailed test (critical value of t-stat $=1.28$ ), consistent with our prediction. 
Table 5: Regression of the Impact of Client Importance on the Accrual-Based Earnings Managemen

\begin{tabular}{|c|c|c|c|c|c|}
\hline $\operatorname{ABSDAC}_{i t}=\alpha_{0}+0$ & $\begin{array}{r}\mathbf{I}_{\mathrm{it}}+\boldsymbol{\alpha}_{2} \mathrm{SIZE}_{\mathrm{i}} \\
\text { STACC } \\
\text { Dependent }\end{array}$ & $\begin{array}{l}\text { Model } 1 \\
+\alpha_{3} \mathrm{CFO}_{\mathrm{it}}+ \\
+\alpha_{7} \mathrm{SGRW}_{\mathrm{it}} \\
\text { Variable: } \mathrm{AB}\end{array}$ & $\begin{array}{l}{ }_{4} \mathbf{L E V}_{\mathrm{it}}+ \\
\varepsilon_{\mathrm{it}} \\
\text { DAC }\end{array}$ & $\alpha_{5} \operatorname{LOSS}_{\mathrm{it}}$ & $x_{6} \mathrm{AB}-$ \\
\hline $\begin{array}{c}\text { Independent } \\
\text { Variable }\end{array}$ & Prediction & Coefficient & t-stat & p-value & VIF \\
\hline $\mathrm{C}$ & $?$ & $0.076 * * *$ & 2.858 & 0.004 & \\
\hline CI & - & -0.011 & -1.303 & 0.193 & 1.137 \\
\hline SIZE & $-/+$ & $-0.004 *$ & -1.916 & 0.056 & 1.191 \\
\hline $\mathrm{CFO}$ & - & $-0.164 * * *$ & -5.813 & 0.000 & 1.083 \\
\hline LEV & + & -0.001 & -0.140 & 0.888 & 1.176 \\
\hline LOSS & - & $-0.026 * * *$ & -4.110 & 0.000 & 1.143 \\
\hline ABSTACC & + & $1.006^{* * *}$ & 25.743 & 0.000 & 1.095 \\
\hline SGRW & + & $-0.000 * * *$ & -6.127 & 0.000 & 1.006 \\
\hline Adj R-squared (\%) & & 85.68 & & & \\
\hline F-statistic & & 923.766 & & & \\
\hline $\begin{array}{l}\text { Prob (F- statistic) } \\
\mathrm{n}=1,080\end{array}$ & & 0.000 & & & \\
\hline
\end{tabular}

This result implies that the bigger the proportion of the economic dependence of audit firms toward their clients, the smaller the magnitude level of accrual earnings management. Our result gives interpretation that audit firms in Indonesia that have larger clients and bigger economic dependence to their clients, are less likely to allow earnings management behavior. This result is also consistent with previous research that found larger offices of Big 4 provides higher audit quality and have clients with less earnings management behavior (Francis and $\mathrm{Yu}, 2009$ ).

Four control variables are significant in the expected direction (CFO, LOSS, ABSTACC, SIZE), and the other control variable is not significant at the 0.10 (LEV), or is significant in the opposite direction (SGRW).

\section{Test of Hypothesis $2\left(\mathrm{H}_{2}\right)$}

Hypothesis $\mathrm{H}_{2}$ predicts a positive association between client importance (CI) and going- concern opinion (GCO). Logistic regression in Model 2 (Table 6) has Cox and Snell R-square $53.70 \%$, and Nagelkerke R-square $80.90 \%$ with the value of $-2 \log$ Likelihood 336.233 The result of the test in Model 2 indicates that the coefficient of $\mathrm{CI}\left(\beta_{1}\right)$ is 1.218 (Wald test $=$ 5.923), positive and significant at 0.05 with two-tailed test. This result implies that although the proportion of audit fee in audit firm's portfolio is bigger, audit firms can still maintain their independence, measured by the issuance of going-concern opinion. Our result is consistent with previous studies, which document that larger offices of public accounting firms are more likely to issue going-concern opinion, and give better prediction for financial distress in the upcoming period (e.g., Francis and Yu, 2009).

Five control variables are significant in the expected direction (SIZE, PRIORGC, LEV, LOSS, LLOSS) and the other control variable is not significant at the 0.10 (CASH). 
Table 6: Logistic Regression of the Impact of Client Importance toward Going-Concern Opinion

\begin{tabular}{|c|c|c|c|c|}
\hline \multicolumn{5}{|c|}{ 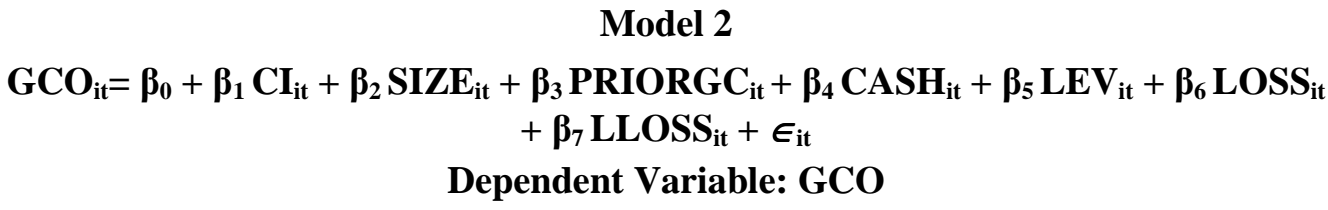 } \\
\hline $\begin{array}{c}\text { Independent } \\
\text { Variable } \\
\end{array}$ & Prediction & Coefficient & Wald & p-value \\
\hline $\mathrm{C}$ & $?$ & $-12.752 * * *$ & 25.499 & 0.000 \\
\hline $\mathrm{CI}$ & + & $1.218^{* *}$ & 5.923 & 0.015 \\
\hline SIZE & + & $0.162 *$ & 2.743 & 0.098 \\
\hline PRIORGC & + & $9.564 * * *$ & 28.244 & 0.000 \\
\hline $\mathrm{CASH}$ & - & 0.049 & 0.002 & 0.969 \\
\hline LEV & + & $1.900 * * *$ & 21.874 & 0.000 \\
\hline LOSS & + & $0.836^{* *}$ & 5.164 & 0.023 \\
\hline LLOSS & + & $1.340 * * *$ & 14.015 & 0.000 \\
\hline -2Log Likelihood & & 336.233 & & \\
\hline Cox \& Snell R ${ }^{2}(\%)$ & & 53.7 & & \\
\hline $\begin{array}{l}\text { Nagelkerke } \mathrm{R}^{2}(\%) \\
\mathrm{n}=1,053\end{array}$ & & 80.9 & & \\
\hline
\end{tabular}

\section{Sensitivity and Robustness Tests}

We use alternate measure of client importance (CI), i.e., client's sales instead of total assets to test the robustness of our main results. Conversely to the hypothesis result of $\mathrm{H}_{1}$, we find no evidence of the association between client importance (CI) and accrual-based earnings management (ABSDAC) at 0.10 (not tabulated). The usage of client importance model using total sales as a proxy becomes sensitiveand do es not support the main result.

Sensitivity test for hypothesis $\mathrm{H}_{2}$ using the same measure of client importance (CI) finds similar result as in the main test (Table 6) (not tabulated). Our result indicates that client importance $(\mathrm{CI})$ has a positive association with going-concern opinion (GCO) at 0.05 . The usage of the different measure of client importance (CI) in Model 2 is robust to all alternative test and support the main result. This result strengthens our main result and previous study (e.g., Francis and Yu 2009), which suggest that larger offices of audit firms are more likely to issue going-concern opinion rather than smaller offices.

\section{CONCLUSION}

Our study investigates the independence of auditors measured by the client importance, and reflected in the accrual-based earnings management and going-concern opinion. The main result of our study finds a negative association between client importance and accrualbased earnings management. Our evidence implies that audit firms with larger clients and with more economic dependence to their clients are less likely to allow earnings management behavior. This result is consistent with previous studies that suggest that larger audit firms, like Big 4 with more expertise and ability to detect earnings management behavior are less likely to allow earnings management rather than smaller audit firms (Francis and Yu 2009; Reynolds and Francis 2001).

Our second main test finds that client importance has a positive association with going-concern opinion. This evidence implies that although the proportion of client dependence is bigger, public accounting firms can maintain their independence measured by the 
issuance of going-concern opinion. Our result is consistent with the previous studies (e.g., Reynolds and Francis 2001) and robust to other sensitivity tests that support the main test result. The combine results indicate that client importance as a measure of auditor independence has a negative association with earnings management and has a positive association with going-concern opinion.

This research has some limitations: (i) the conclusions drawn in this study should be conducted with caution, because we use only single measure of auditor independence, i.e., the client importance. There are some other measurements, such as the influence of client practices toward the propensity to meet earnings targets, and corporate governance practices (Bamber and Bamber 2009); (ii) accrualbased earnings management is the only measure of earnings management used in this study. Previous research documented several other earnings management techniques, such as real earnings management, and classification shifting (e.g., Cohen and Zarowin 2010; Fan et al. 2010).

We recommend for further study to use the composite measure of independence. Herusetya (2012) for example, the use composite measures of audit quality from the dimension of competency and independence. In order to reflect the different aspect of earnings management, we also recommend to examine the other tools of earnings management, such as real earnings management and classification shifting (Cohen and Zarowin 2010; Graham et al. 2005).

\section{REFERENCES}

Acock, A.C. 2008. A Gentle introduction to stata. 2nd ed. Texas: A Stata Press Publication, StataCorp LP.

Balsam, S., J. Krishnan, and J.S. Yang. 2003. Auditor industry specialization and earnings quality. Auditing: A Journal of Practice and Theory 22 (2): 71-97.

Bamber, E.M., and L.S. Bamber. 2009. Discussion of mandatory audit rotation, audit quality and market perception:
Evidence from Taiwan. Contemporary Accounting Research 26 (2): 392-402.

Barton, J., and P.J. Simko. 2002. The Balance sheet as an earnings management constraint. The Accounting Review 77: 127.

Becker, C.L., M.L. Defond, J Jiambalvo, and K.R Subramanyam. 1998. The Effect of audit quality on earnings management. Contemporary Accounting Research 15 (1): 1-24

Challen, A.E., and S.V. Siregar. 2011. The Effect of audit quality on earnings management and firm value. Working Paper, October 8-12, 2011, Bali, Indonesia: The 12th Asian Academic Accounting Association.

Chen, S., S.Y.J.S. Sun, and D. Wu. 2010. Client importance, institutional improvements, and audit quality in China: An office and individual auditor level analysis. The Accounting Review 85 (1): 127-158.

Chi, W., L.L. Lisic, and M. Pevzner. 2011. Is enchanced audit quality associated with greater real earnings management? Accounting Horizons 25 (2): 315-325.

Chung, H., and S. Kallapur. 2003. Client importance, non-audit services, and abnormal accruals. The Accounting Review 78 (4): 931-955.

Coffee, J.C. Jr. 2003. Gatekeeper failure and reform: the challenge of fashioning relevant reforms. Working Paper no. 237, Columbia Law School, The Center for Law and Economic Studies.

Coffee, J.C. Jr. 2002. Understanding enron: it's about the gatekeepers, stupid. Working Paper no. 207, Columbia Law School, The Center for Law and Economic Studies.

Cohen, D.A., A. Dey, and T.Z. Lys. 2008. Real and accrual based earnings management in the pre- and post- sarbanes 
oxley periods. The Accounting Review 83 (3): 757-787.

Cohen, D.A., and P. Zarowin. 2010. Accrualbased and real earnings management activities around seasoned equity offerings. Journal of Accounting and Economics 50 (1): 2-19.

Craswell, A., D.J. Stokes, and J. Laughton. 2002. Auditor independence and fee dependence. Journal of Accounting and Economics 33 (2): 253-275.

DeAngelo, L.E. 1981. Auditor size and audit quality. Journal of Accounting and Economics 3: 183-199.

Dechow, P.M., and M.C. Schrand. 2004. Earnings Quality. USA: The Research Foundation for CFA Institute.

Dechow, P.M., R.G. Sloan, and A.P. Sweeney. 1995. Detecting earnings management. The Accounting Review 70 (2): 193225.

Departemen Keuangan Republik Indonesia, Badan Pengawas Pasar Modal dan Lembaga Keuangan. 2008. Salinan Keputusan Ketua Badan Pengawas Pasar Modal dan Lembaga Keuangan Nomor: KEP-310/BL/2008 Tentang "Independensi Akuntan yang Memberikan Jasa di Pasar Modal". Jakarta, 1 Agustus 2008.

Fan, Y., A. Barua, W.M. Cready, and W.B. Thomas. 2010. Managing earnings using classification shifting: evidence from quarterly special items. The Accounting Review 85 (4): 1303-1323.

Fargler, N.L., and L. Jiang. 2008. Changes in the audit environment and auditors' propensity to issue going concern opinions. Auditing: A Journal of Practice \& Theory 27 (2): 55-77.

Fitriany. 2011. Analisis Komprehensif Pengaruh Kompetensi dan Independensi Akuntan Publik Terhadap Kualitas Audit. Jakarta: Disertasi, Fakultas
Ekonomi, Program Pascasarjana Ilmu Akuntansi, Universitas Indonesia.

Francis, J.R. 2004. What do we know about audit quality? The British Accounting Review 36 (4): 345-368.

Francis, J.R., and M.D. Yu. 2009. Big 4 office size and audit quality. The Accounting Review 84 (5): 1521-1552.

Frankel, R.M., M.F. Johnson, and K.K. Nelson. 2002. The Relation between auditors's fee for non-audit services and earnings management. The Accounting Review 77: 71-105.

Geiger, M.A., K. Raghunandan, and D.V. Rama. 2005. Recent changes in the associations between bankruptcies and prior audit opinions. Auditing: A Journal of Practice \& Theory 24 (1): 21-35.

Geiger, M.A., and D.V. Rama. 2006. Audit firm size and going concern reporting accuracy. Accounting Horizons 20 (1): $1-17$.

Gordon, E. A., A. Greiner, M. J. Kohlbeck, S. Lin, and H. Skaife. 2013. Challenges and opportunities in cross-country accounting research. Accounting Horizons 27 (1): 141-154.

Graham, J.R., C.R. Harvey, and S. Rajgopal. 2005. The economic implications of corporate financial reporting. Journal of Accounting and Economics 40: 3-73.

Gujarati, D.N. 2003. Basic econometrics. 3rd ed. New York: McGraw-Hill, Inc.

Hermawan, A. A. 2009. Pengaruh efektifitas dewan komisaris dan komite audit, kepemilikan oleh keluarga, dan peran monitoring bank terhadap kandungan informasi laba. Jakarta: Disertasi, Pascasarjana Fakultas Ekonomi, Universitas Indonesia.

Herusetya, A. 2012. Analisis audit quality metric score (AQMS) sebagai pengukur multidimensi kualitas audit terhadap manajemen laba dan kandungan informasi laba. Jakarta: Disertasi, Pasca- 
sarjana Fakultas Ekonomi Universitas Indonesia.

Kothari, S.P., A.J. Leone, and C.E. Wasley. 2005. Performance matched discretionary accrual measures. Journal of Accounting and Economics 39: 163-197.

Levitt, A. 1998. The number game. A Speech delivered at the NYU Center for Law of Business, New York. Available at http://www.sec.gov/spch220.txt.

Li, C. 2009. Does client importance affect auditor independence at the office level? Empirical Evidence from goingconcern opinions. Contemporary Accounting Research 26 (1): 201-230.

Marchesi, M.F. 2000. Audit quality in ASEAN. The International Journal of Accounting 35 (1): 121-149.

McNichols, M. 2000. Research design issues in earnings management studies. Journal of Accounting and Public Policy 19: 313-345.

Menon, K., and D.D. Williams. 2004. Former audit partners and abnormal accruals. The Accounting Review 79 (4): 10951118.

Menteri Hukum dan Hak Asasi Manusia Republik Indonesia. 2011. UndangUndang Republik Indonesia Nomor 5
Tahun 2011 tentang Akuntan Publik. Diundangkan di Jakarta pada tanggal 3 Mei 2011, Lembar Negara Republik Indonesia Tahun 2011 No. 51.

Myers, J., L.A. Myers, and T.C. Omer. 2003. Exploring the term of the auditorclient relationship and the quality of earnings: A Case of mandatory auditor rotation? The Accounting Review 78 (3): 779-799.

Reynolds, K.J., and J.R. Francis. 2001. Does size matter? The influence of large clients on office-level auditor reporting decisions. Journal of Accounting and Economics 30 (3): 375-400.

Siregar, S.V.N.P., and S. Utama. 2006. Pengruh struktur kepemilikan, ukuran perusahaan, dan praktek corporate governance terhadap pengelolaan laba (earnings management). Jurnal Riset Akuntansi Indonesia 9 (3): 307-326.

Tresnaningsih, E. 2008. Manajemen laba pada perusahaan dengan permasalahan free cash flow dan peran moderasi dari monitoring eksternal. Jurnal Akuntansi dan Keuangan Indonesia 5 (1): 30-49.

Wooldridge, J.M. 2009. Introductory econometrics- a modern approach. 4th ed. South-Western, Cengage Learning Asia.

\footnotetext{
${ }^{1}$ For example, the Indonesian Government issued a number of regulations concerning the independence and competence of auditors and audit firms, such as: KEP-310/BL/2008 regarding "The Independence of Accountant Providing Services in the Capital Markets in 2008"; and The Act No. 5 for the Public Accountants in 2011.

${ }^{2}$ Recent research found that public listed companies not only did accrual-based earnings management, but also real-based transactions (e.g., Cohen and Zarowin, 2010; Graham, Harvey, and Rajgopal, 2005; Chi, Lisic \& Pevzner, 2011; Challen and Siregar, 2011). Other research found other earnings management tools, such as classification shifting (Fan, Barua, Cready \& Thomas, 2010).

${ }^{3}$ Frankel et al. (2002) found evidence of a positive association between client importance, i.e., the ratio of non-audit services fee to total fee and the amount of discretionary accruals. The findings and methodology used by Frankel et al. (2002) were questioned by many researchers. Chung and Kallapur (2003) for example, found that the association of the ratio of non-audit to total fee and absolute abnormal accruals are less robust, because it did not include control variable of each industry.

${ }^{4}$ Francis and Yu (2009) for exception, found no evidence of the association between economic dependence and auditor's goingconcern opinion.

${ }^{5}$ Our sample consist of $53.33 \%$ from manufacture industry (basic and chemical industry, consumer goods, and miscellaneous), $32.59 \%$ from trade, service \& investment, and $14.07 \%$ from property \& real estate industry.

${ }^{6}$ For accrual model used, our study requires a minimum of 15 observations for each type of industry each year (Chi et al., 2011; Cohen et al., 2008).

${ }^{7}$ All continuous data are winsorized to avoid outliers using 2 standard deviations from the mean, so that the data is spread over an area of $95.45 \%$ (Acock, 2008). All variables in Table 3, Panel A and B have low standard deviation except for SGRW.
} 


\footnotetext{
${ }^{8}$ We test for multicollinearity problem and found that all variables have small value of VIF (below 1.50). The tolerance (TOL) value of all variables are also close to 1.00, indicating that there are no multicollinearity problem (Gujarati, 2003; Nachrowi and Usman, 2006). While the test for heteroscedasticity indicates that there is a problem with heteroscedasticity, but we treat using the Huber-White procedure to correct heteroscedasticity in order to get estimated coefficient from robust variance-covariance (Wooldridge, 2009).

${ }^{9}$ We eliminate 27 outliers out of 1080 firm-years observation to obtain robust standard errors. We also test whether there is a multicollinearity problem in our empirical model, and found that all independent variables have VIF value below 1.50, indicating that there is no multicollinearity problem (Gujarati, 2003). Our logistic regression has $\mathrm{Chi}^{2}=3.930(\mathrm{p}>0.10)$ for Hosmer and Lemeshow test, indicating that the data and model used are fit.
} 